\title{
Business Attributes and Marketing Communication Strategies of SMEs in South Africa
}

\author{
Morongwa Ramasobana, Olawale Fatoki \\ Department of Business Management, University of Limpopo, South Africa \\ morongwa.ramasobana@ul.ac.za, olawale.fatoki@ul.ac.za
}

\begin{abstract}
The purpose of this study was to investigate business attributes and marketing communication practices of SMEs in South Africa. This study adopted the quantitative research design with a descriptive research method. Data was collected through the use of self-administered questionnaires in a survey. Descriptive statistics, ANOVA and regression analysis were used to analyse data. The results revealed that some marketing communication tools indicate that there is no significant difference in the marketing communication tools adopted by SMEs on the basis of business attributes. In addition, some marketing communication tools indicated that there is a significant difference in the marketing communication tools adopted by SMEs on the basis of business attributes. This study recommended that SMEs' owners should consider their business factors when selecting the marketing communication strategies and equip themselves with the knowledge of marketing communication.
\end{abstract}

Keywords: Marketing communication, SMEs, business attributes

\section{Introduction}

Small and Medium-Sized Enterprises (SMEs) are critical drivers of economic growth, employment creation and poverty alleviation in both developed and developing countries (Nkosi, Bounds \& Goldman, 2015:1). According to Steyn \& Leonard (2012:24), SMEs serve as the primary means of sustainable industrial and social diversification of the society, thus becoming one of the main drivers of economic development in the majority of countries. Muritala, Awolaja and Bako (2012:18) posit that the majority of developed and developing countries rely heavily on risk tasking, dynamism and the resourcefulness of small and medium enterprises to trigger and sustain the process of economic growth. The development of small and medium enterprises is therefore an essential strategy to grow the economy of South Africa (Monks, 2010:3).However, the sustainability of SMEs has been a subject of concern in South Africa. Adeniran and Johnston (2011:1) note that despite the importance of the SME sector, it is estimated that the failure rate of SMEs in South Africa is between $70 \%$ and $80 \%$. Various factors can be attributed to this failure. Van Scheers (2010:5050) posits that SMEs do not have access to finance and marketing skills. Marketing communication is one of the key factors to the survival of SMEs in South Africa.Existing literature on marketing communication in South Africa observed factors such as integrated marketing communication for SMEs (Gabrieli \& Balboni, 2010), marketing resources and firm performance among SMEs (Spillan \& Parnell 2006), marketing knowledge and strategy for SMEs (Marjanova \& Stojanovski, 2012). This study seeks to examine the effect of business attributes on the choice of marketing communication strategies of SMEs in South Africa. Businesses attributes considered for this study includes the size of the business, the sector, access to finance and the age of SMEs. According to the researcher's knowledge, no study has investigated the effect of business attributes on the choice of marketing communication tools in SMEs. This gap in the literature has stimulated this study.

Objective of the study: The objective of the study was to examine the effect of business attributes on the choice of marketing communication strategies of SMEs.

\section{Hypotheses}

Ho1: There is no significant difference in the marketing communication tools adopted by SMEs on the basis of the size of SMEs.

Ha1: There is a significant difference in the marketing communication tools adopted by SMEs on the basis of the size of SMEs.

Ho2: There is no significant difference in the marketing communication tools adopted by SMEs on the basis of the sector of the SME.

Ha2: There is a significant difference in the marketing communication tools adopted by SMEs on the basis of the sector of the SME. 
Ho3: There is no significant difference in the marketing communication tools adopted by SMEs on the basis of access to finance.

Ha3: There is a significant difference in the marketing communication tools adopted by SMEs on the basis of access to finance.

Ho4: There is no significant difference in the marketing communication tools adopted by SMEs on the basis of the age of the SME.

Ha4: There is a significant difference in the marketing communication tools adopted by SMEs on the basis of the age of the SME.

\section{Literature Review}

This study provides the theoretical literature review of business attributes and marketing communication practices adopted by SMEs.

Theoretical background of marketing communication: Integrated Marketing Communication (IMC) theory by Schultz (1996) provides the theoretical framework for this study. IMC is the integration of different marketing communication techniques such as traditional and guerrilla marketing strategies to provide added value to the customer, and to increase positive relationships with all stakeholders (Du plessis, Van heerden \& Cook 2010:19). Schultz posits that consumers integrate all messages received from an organisation. Therefore, if the organisation transmits uncoordinated messages to the same consumer, that consumer will aggregate and integrate those messages according to some pattern. Gabrielli and Balboni (2010:287) assert that SMEs are able to use various communication tools (IMC), including both traditional and guerrilla marketing tools, to declare ambitions and long-term goals, as well as to define in-depth messages. The use of traditional and guerrilla marketing communication techniques will allow SMEs to send complete messages through different mediums/channels to customers. Both traditional and guerrilla marketing strategies contribute differently to integrated marketing communication (IMC). Kailani (2012:122) finds that traditional marketing contributes to integrated marketing communication in the form of marketing communication mix. Du plessis, Van heerdenand Cook (2010:19) define IMC as the combination of advertising, publicity, public relations, personal selling, sales promotion, sponsorship, direct marketing and digital communication. Guerrilla marketing has a unique method of contributing to IMC. Anukam (2014:180) posit that guerrilla marketing strategies can be undertaken in a traditional way. For example, buzz marketing can emanate from public relations and publicity.

Marketing communication practices adopted by SMEs: According to Marcomm (2006:221), marketing communications are all strategies, techniques, and activities involved in delivering the desired marketing messages to intended target markets, regardless of the media choice. In this study, marketing communication is defined as the use of guerrilla and/or traditional marketing tools to effectively communicate with customers.

Guerrilla marketing: Teoh (2012:2) defines guerrilla marketing as the promotion of advertisement with a low budget, in an unconventional way to make the consumer have an ineradicable impression and to create ample amount of social buzz. According to Ujwala (2012:122), guerrilla marketing has been proven to work for SMEs around the world for the reasons that it is simple to understand, easy to implement and inexpensive. As a form of guerrilla marketing, Dlodlo and Dhurup (2013:55) posit that SMEs should incorporate internetdriven marketing principles such as e-marketing into their business practices. SMEs use viral marketing through social media platforms such as Facebook, blogs, LinkedIn, YouTube and twitter to minimise marketing costs (Dzisi \& Ofosu, 2014:106).

Traditional marketing: Higuera (2015:1) asserts that traditional marketing refers to any form of promotion, advertising or campaign in the form of print advertisements such as billboards, newsletters, flyers and newspaper print advertising. Abdul-Rahim, Wahab and Saad (2015:135) report that traditional media is limited to a one-to-many approach, an approach in which a business can communicate with many people in a way that is one-directional. For example, customers can listen to an advertisement on radio, but will not be able to respond verbally to the advertisement (Nekatibebe, 2012:20). According to Ruzzier, Ruzzier and Hisrich (2013:222), SMEs use cost-effective forms of media such as advertising on local rather than on 
national TV, or use cable channels such as radio and newspapers. SMEs use direct marketing, public relations, publicity, personal selling and sales promotion to effectively communicate with customers (Du plessis, Van heerden \& Cook, 2010:36).

Business attributes: Suttle (2016:1) defines business attributes as characteristics that best represent all brands or businesses in the marketplace. Business attributes include size and the age of the business (Coad \& Tamvada, 2012:384). Business attributes considered for this study include the size of the business, sector/ industry of the business, age of the business and access to finance.

Size of the business: Marketing communication is determined by various factors in SMEs (Ruzzier, Ruzzier \& Hisrich 2013:231). The size of the business can determine its marketing communication practices. Marjanova and Stojanovski (2012:136) point out that SME marketing is based on inherent SME characteristics such as the SME size. According to Gabrielli and Balboni (2010:281), traditional marketing, which is a broad category that incorporates many forms of advertising and marketing such as print, broadcast, direct mail and telemarketing, can be adopted and adapted for small businesses. Thrassou and Vrontis (2007:191) posit that small service SMEs, despite having an informal approach to marketing communications, spend more time communicating and engaging with their customers than larger firms. SMEs with a conservative approach to marketing might advertise in a local newspaper using commonplace advertising, while a large firm that uses entrepreneurial marketing might launch a sophisticated advertising campaign (Marjanova \& Stojanovski, 2012:135). According to Centeno and Hart (2012:251), microenterprises do little of traditional marketing activities because of their size; the marketing communication messages are not targeting a very large audience as compared to small and medium-sized enterprises. The above findings indicate a significant difference in the marketing communication tools adopted by SMEs on the basis of SME size.

Sector/ industry of the business: SMEs formulate parts of different business industries/sectors and engage in various marketing communication techniques depending on the business industry (Rabova, 2015:49). According to Ramsey and Ibbotson (2006:317), the majority of manufacturing SMEs are still in the lower stages of e-business adoption because these businesses perceive very low levels of benefit from e-business. This is consistent with the view by Esteves (2009:27) that the majority of manufacturing SMEs are in the lower stages of e-marketing adoption as these firms perceive very low levels of supply chain benefits from ebusiness. Šerić and Gil-Saura (2011:283) are of opinion that public relations and product placement were used as a substitute for advertising when creating publicity in the tourism industry. Wang, Wu and Yuan (2009:219) posit that SMEs in the heritage destination (tourism sector) communicate with their customers through public relations and advertisements. Opoku, Abratt, Bendixen and Pitt (2007:363) suggest that a retailer's web site is an important part of its communications strategy, and therefore, managers should focus on the message that their web site is portraying. Gurau (2008:17) agrees that some retail SMEs monitor the communication between the online user and their web site; and the time spent by a customer on a specific web page can indicate his/her present interest in the products. Retailers use the data provided by their online behaviour monitoring system to produce personalized promotions targeted to individual customers. Spence and Essoussi (2010:1048) find that manufacturing SMEs communicate their brands or products through the use of web sites that support the positioning of both the brands and products. Based on the above literature, it is evident that there is a significant difference in the marketing communication tools adopted by SMEs on the basis of the sector of the SME.

Access to finance and the age of the business: Rogerson (2008:62) observes that one of the primary causes of SME failure in South Africa is the non-availability of external finance. Beck and Bemirguc-kunt (2006:2941) remark that SMEs are more constrained by limited access to finance, and with the absence of well-developed financial markets, it is difficult for SMEs to grow to their optimal size. The availability of finance has been stressed out as a key factor in the development, growth and success of SMEs (Abdulsaleh \& Worthington, 2013:36). According to Rakaumba (2014:25), as compared to medium-sized enterprises, small businesses often lack financial records and the collateral required for loans from commercial banks. A total of $75 \%$ of applications for credit by new businesses are rejected while only two percent of new SMEs are able to access loans (Finscope, 2010:2). The initial expenditure of getting any SME to function is also high, and as such, marketing cost does not take priority (Kroon \& Moolman, 2007:18). SMEs are financially constrained, and therefore do not have enough budget to spend on traditional marketing communication (Kudryavtseva, 
2012:2). SMEs can rather resort to guerrilla marketing mainly because it is inexpensive (Teoh, 2012:2). Financial assistance helps SMEs to grow, meaning that most SMEs which already had a long lifespan were financially assisted and are now sustainable (Fatoki, 2012:122). According to Ruzzier, Ruzzier and Hisrich (2013:231), sustainable SMEs can be able to have enough budgets for traditional marketing communication, whereas relatively new SMEs will not have enough budgets for traditional marketing and will rather engage in guerrilla marketing. Based on the above findings, there is a significant difference in the marketing communication tools adopted by SMEs on the basis of access to finance and age of the SMEs.

\section{Methodology}

Quantitative research methodology was considered for this study because the research was subject to verifiability, which provided an air of legitimacy and reliability (Struwig \& Stead, 2013:139). This study focused on SMEs located in Polokwane Local Municipality in Limpopo Province, South Africa. Non probability sampling was deemed appropriate for this study because of the difficulty in obtaining a list of SMEs in the study area. The study used convenience sampling and snowball sampling methods because; there was no defined population frame of SMEs in the research area. In addition, the researcher wanted to include the very small enterprises which majority of them are not registered. The researcher used self-administered questionnaire to collect data because, this method has proved to have a higher response rate than other data gathering techniques such as mail surveys (Grix, 2010:213). The questionnaire was developed by the researcher after a thorough review of literature on marketing communication strategies and SMEs. A total of 370 questionnaires were distributed to respondents, but only 160 were returned. Descriptive statistics, ANOVA and regression analysis were used to analyse data. Descriptive statistics was used to narrow down biographical details of the respondents. ANOVA and regression analysis were used to establish the variance between the following: (1) the size of SMEs and marketing communication; (2) SMEs' access to debt finance and marketing communication; and (3) the age of the business and marketing communication. The Cronbach's alpha test was used to measure reliability of the questionnaire items.

\section{Results and Discussions}

One hundred and sixty SME owners participated in the study.

Table 1: Biographical details of the respondents

\begin{tabular}{ll}
\hline Biographical details & Frequency \\
\hline Gender & 109 \\
Male & 51 \\
Female & \\
Age of the owner & 1 \\
Below 20 & 57 \\
$20-30$ & 32 \\
$31-40$ & 47 \\
$41-50$ & 23 \\
Above 50 & \\
Qualification of the owner & 19 \\
Below Matric or equivalent & 55 \\
Matric or equivalent & 86 \\
Above Matric & \\
Access to internet & 43 \\
Yes & 117 \\
No & \\
Number of years of business operation & 4 \\
Below one year & 28 \\
1-5 years & 16 \\
6-10 & 2 \\
Above 10 & \\
Access to debt finance &
\end{tabular}




\begin{tabular}{ll} 
Yes & 25 \\
No & 135 \\
Number of employees & \\
0 & 1 \\
$1-5$ & 51 \\
$6-20$ & 15 \\
$21-50$ & 11 \\
$51-200$ & 34 \\
\hline
\end{tabular}

Biographical details of the respondents: Table 1 depicts the biographical details of the participants. The majority of the participants are male, in the 20-30 age bracket, with post matric qualification. The respondents do not have access to internet and debt finance. Their businesses have existed for between one and five years and have between one and five employees.

Table 2: Business attributes and marketing communication strategies of SMEs

\begin{tabular}{|c|c|c|c|c|c|c|}
\hline & & $\begin{array}{l}\text { Sum } \\
\text { Squares }\end{array}$ & of & Mean Square & $\mathbf{F}$ & Sig. \\
\hline \multirow{3}{*}{ Size of the business } & Between Groups & 99.046 & 2 & 49.523 & 29.379 & 0.000 \\
\hline & Within Groups & 264.648 & 157 & 1.686 & & \\
\hline & Total & 363.694 & 159 & & & \\
\hline \multirow[t]{3}{*}{ industry of the business } & Between Groups & 1.571 & 2 & 0.785 & 0.878 & 0.418 \\
\hline & Within Groups & 140.404 & 157 & 0.894 & & \\
\hline & Total & 141.975 & 159 & & & \\
\hline \multirow[t]{3}{*}{ Access to debt finance } & Between Groups & 1.779 & 2 & 0.889 & 7.230 & 0.001 \\
\hline & Within Groups & 19.315 & 157 & 0.123 & & \\
\hline & Total & 21.094 & 159 & & & \\
\hline \multirow[t]{3}{*}{ Age of the business } & Between Groups & 38.262 & 2 & 19.131 & 9.598 & 0.000 \\
\hline & Within Groups & 312.932 & 157 & 1.993 & & \\
\hline & Total & 351.194 & 159 & & & \\
\hline
\end{tabular}

Business attributes and marketing communication strategies of SMEs: Table 2 depicts the effect of business attributes on marketing communication strategies of SMEs. The results indicate that there is a significant difference in the marketing communication tools adopted by SMEs on the basis of the size of SMEs. Therefore; Ha1 is accepted. These findings are consistent with Centeno and Hart (2012:251) indicating that micro enterprises do little of traditional marketing activities and because of their size, the marketing communication messages are not targeting a very large audience as compared to small and medium-sized enterprises. The results also indicated that there is no significant difference in the marketing communication tools adopted by SMEs on the basis of the sector of the SME. Therefore; Ho2 is accepted. These findings are inconsistent with Rabova (2015:49) indicating that SMEs engage in various marketing communication techniques depending on the business industry.In addition, the results indicated that there is a significant difference in the marketing communication tools adopted by SMEs on the basis of access to finance. Therefore; Ha3 is accepted. These findings are consistent with Rakaumba (2014:25) indicating that, as compared to medium-sized enterprises, small businesses often lack financial records and the collateral required for loans from commercial banks. Furthermore, the results indicated that there is a significant difference in the marketing communication tools adopted by SMEs on the basis of the age of SMEs. Therefore; Ha4 is accepted. These finding are consistent with Ruzzier, Ruzzier and Hisrich (2013:231) highlighting that SMEs that already have a long lifespan can be able to have enough budget for traditional marketing communication, whereas relatively new SMEs will not have enough budget for traditional marketing and will rather engage in guerrilla marketing. The above results are further supported by the regression analysis below. 
Table 3: Business attributes and marketing communication strategies of SMEs

\begin{tabular}{llllll}
\hline \multicolumn{7}{c}{} & \multicolumn{2}{l}{$\begin{array}{l}\text { Unstandardized } \\
\text { Coefficients }\end{array}$} & $\begin{array}{l}\text { Standardized } \\
\text { Coefficients } \\
\text { Model }\end{array}$ & B & Std. Error & Beta & t & Sig. \\
\hline (Constant) & 3.655 & 0.385 & & 9.491 & 0.000 \\
Size of the business & 0.246 & 0.051 & 0.576 & 4.835 & 0.000 \\
industry of the business & 0.47 & 0.107 & 0.026 & 0.438 & 0.662 \\
Access to debt finance & -0.530 & 0.142 & -0.299 & -3.734 & 0.000 \\
Age of the business & -0.129 & 0.049 & -0.296 & -2.642 & 0.009 \\
\hline
\end{tabular}

Dependent Variable: Marketing communication

Table 3 depicts the effect of business attributes on marketing communication strategies of SMEs. The results indicate that there is a significant difference in the marketing communication tools adopted by SMEs on the basis of the size of SMEs. Therefore; Ha1 is accepted. The results also indicated that there is no significant difference in the marketing communication tools adopted by SMEs on the basis of the sector of the SME. Therefore; Ho2 is accepted. In addition, the results indicated that there is a significant difference in the marketing communication tools adopted by SMEs on the basis of access to finance. Therefore; Ha3 is accepted. Furthermore, the results indicated that there is a significant difference in the marketing communication tools adopted by SMEs on the basis of the age of the SME. Therefore; Ha4 is accepted.

\section{Conclusion}

The high failure rate of SMEs in South Africa can be linked to various aspects. While extensive debates and research have been directed on the financing aspect, limited research has been conducted in the area of marketing and SME attributes. The objective of the study was to examine the effect of business attributes on the choice of marketing communication strategies of SMEs in South Africa. This study concludes that there are significant differences between business attributes and the majority of marketing communication tools used by SMEs.

Recommendations: SMEs in the study area should consider their business attributes such as the size of the business and the access to finance when selecting marketing communication tools. This will enable them to select marketing communication tools that are within their budget, effectively communicate with their stakeholders and be sustainable. SMEs' owners/ managers need to use the available development programmes from organisations that assist them with training and finance such as the Small Enterprise Development Agency (SEDA) to equip themselves with relevant knowledge on the issue pertaining the adoption and utilisation of marketing communication strategies.In addition, the findings of this study can help these organisations that support SMEs in South Africa to better understand the marketing communication strategies adopted by SMEs and to design intervention mechanisms to improve the marketing function of SMEs.The government can also subsidise the marketing function of SMEs in order to sustain them. This support from the government will enable SMEs to have funds in order to engage in both traditional and guerrilla marketing strategies to improve their performance and be profitable.

\section{References}

Abdul-Rahim, H., Wahab, K. \& Saad, A. (2015). The shift from traditional marketing to entrepreneurial marketing practices: A literature review. Business and Management Studies, 1(2), 134-139.

Abdulsaleh, A. M. \& Worthington, A. C. (2013). Small and medium-sized enterprises financing: A review of literature. International Journal of Business and Management, 8(14), 36-54.

Adeniran, T. \& Johnston, A. (2011). Investigating the level of internet capabilities of South African small and medium enterprises in changing environments. From: www.zaw3.co.za/index.php/ZAWWW/2011/paper/view/450 [Accessed 23 February 2015].

Anukam, A. J. (2014). Analysis guerrilla and traditional marketing interface in improving the productivity of organizational marketing in small and medium size enterprises (SMEs) in Nigeria. Journal of Small Business and Entrepreneurship Development, 2(1), 175-190. 
Beck, T. \& Demirguc-Kunt, A. (2006). Small and medium-size enterprises: Access to finance as a growth constraint. Journal of Banking and Finance, 30(11), 2931-2943.

Centeno, E. \& Hart, S. (2012).The use of communication activities in the development of small to mediumsized enterprise brand. Journal of Marketing Intelligence and Planning, 30(2), 250-265.

Coad, A. \& Tamvada, J. P. (2012).Firm growth and barriers to growth among small firms in India. Small business economics, 39(2), 383-400.

Dlodlo, N. \& Dhurup, M. (2013).Drivers of E-Marketing adoption among small and medium enterprises (SMEs) and variations with age of business owners. Mediterranean Journal of Social Sciences, 4(14), 53-60.

Du Plessis, F., Van heerden, N. \& Cook, G. (2010). Integrated marketing communication. Pretoria, South Africa: Van Schaik publishers.

Dzisi, S. \& Ofosu, D. (2014).Marketing strategies and the performance of SMEs in Ghana. European Journal of Business and Management, 6(5), 102-111.

Esteves, J. (2009). A benefits realization road-map framework for ERP usage in small and medium sized enterprises. Journal of Enterprise and Information Management, 22(1-2), 25-35.

Fatoki, 0. (20120.The impact of entrepreneurial orientation on access to debt finance and performance of small and medium enterprises in South Africa. Journal of Social Science, 32(2), 121-131.

Finscope. (2010). South Africa small business survey. From: www.btrust.org.za/...finscope_small_business_survey... [Accessed 15 March 2014].

Gabrieli, V. \& Balboni, B. (2010). SMEs practice towards integrated marketing communications. Marketing Intelligence and Planning, 28(3), 275-290.

Grix, J. (2010).The foundation of research. New York: Palgrave Macmillan.

Gurau, C. (2008). Integrated online marketing communication: implementation and management. Journal of Communication Management, 12(2), 169 - 184.

Higuera, V. (2015).Advantages \& disadvantages of traditional marketing. From: http://smallbusiness.chron.com/advantages-disadvantages-traditional-marketing-25573.html [Accessed 11 January 2015].

Kailani, C. M. (2012). Impact of integrated marketing communication on consumer behaviour: effects on consumer decision - making process. International Journal of Marketing Studies, 4(2), 121-129.

Kroon, J. \& Moolman, P. L. (2007).Entrepreneurship. Pretoria: Kagiso Publishers.

Kudryavtseva, A. (2012).Guerrilla marketing: new concept in practice sport master case. From: www.yumpu.com/.../guerrilla-marketing-new-concept-in-practice [Accessed 11 June 2014].

Marcomm, W. S. (2006). Performance consequences of brand equity management: evidence from organisations in the value chain. Journal of Product and Brand Management, 12(4), 220-236.

Marjanova, J. T. \& Stojanovski, M. (2012).Marketing knowledge and strategy for SMEs: Can they live without it? From: eprints.ugd.edu.mk/2084/1/MARKETING KNOWLEDGE AND... [Accessed 14 June 2016].

Monks, P. G. S. (2010). Sustainable growth of SMEs.MBA Thesis. South Africa. Nelson Mandela Metropolitan University.

Muritala, T. A., Awolaja, A. M. \& Bako, Y. A. (2012).Impact of small and medium enterprises on economic growth and development. American journal of business and management, 1(1), 18-22.

Nekatibebe, T. (2012).Evaluating the impact of social media on traditional marketing. Bachelor of Business Administration Thesis. Finland. Helsinki Metropolia University of applied sciences.

Nkosi, E., Bounds, M., Thomas, A. \& Goldman, G. (2015). Corrigendum: Skills required for the management of black-owned small enterprises in Soweto. ActaCommercii, 13(1), 1-10

Opoku, R. A., Bendixen, M., Abratt, R. \& Pitt, L. (2007). Communication brand personality: are the web sites doing the talking for food SMEs? Qualitative market research: An International Journal, 10(4), 362374.

Rabova. T. K. (2015). Marketing communication of SMEs specialized in cosmetic industry in magazines for women. Procedia - Social and Behavioural Sciences, 175, 48 - 57.

Rakaumba, T. (2014). Overcoming SMEs challenges through critical success factors: A case of SMEs in the Western Cape Province, South Africa. Economic and Business Review, 16(1), 19-38.

Ramsey, E. \& Ibbotson, I. (2006). E-Entrepreneurial SMEs: an Irish study of Micro and Macro influences. Journal of International Entrepreneurship, 3(1), 317-332.

Rogerson, C. M. (2008).Tracking SMME development in South Africa: Issues of finance, training and regulatory environment. Urban Forum, 19(1), 61-81. 
Ruzzier, M. K., Ruzzier, M. \& Hisrich, R. D. (2013).Marketing for entrepreneurs and SMEs: A global perspective. United Kingdom: Edward Elgar publishing limited.

Schultz, D. E. (1996).The inevitability of Integrated Communication. Journal of Business Research, 37(1), 139146.

Šerić, M. \& Gil-Saura, I. (2012). ICT, IMC, and brand equity in high-quality hotels of Dalmatia: An analysis from guest perceptions. Journal of Hospitality Marketing \&Management, 21(8), 821-851.

Spence, M. \& Essoussi, L. M. (2010). SME brand building and management: an exploratory Study. European Journal of Marketing, 44(7/8), 1037 - 1054.

Spillan, J. \& Parnell, J. (2006). Marketing resources and firm performance among SMEs. European Management Journal, 24(2-3), 1-18.

Steyn, A. A. \& Leonard, A. C. (2012). Guidance for SMEs with the adoption of technology: a conceptual framework. South African Journal of Entrepreneurship and Small Business Management, 5(1), 24-33.

Struwig, F. W. \& Stead, G. B. (2013). Research: planning, designing and reporting. South Africa: Pearson education South Africa (Pty) Ltd.

Suttle, R. (2016).What does attribute mean in business? From: smallbusiness.chron.com/attribute-meanbusiness-24039.html [Accessed 29 June 2016].

Teoh, T. (2012).The review of the latest findings on guerrilla marketing. From: www.researchgate/.../258315689-THE-REVIEW-OF-THE-LATEST- [Accessed 02 May 2014].

Thrassou, A. \& Vrontis, D. (2007). A small services firm marketing communications model for SME-dominated environments. Journal of Marketing Communications, 12(3), 183-202.

Ujwala, B. (2012). Insights of guerrilla marketing in business scenario. International Journal of Marketing, Financial Services \& Management Research, 1(10), 120-128.

Van scheers, L. (2011). SMEs marketing skills challenges in South Africa. African journal of Business Management, 5(13), 5048-5056

Wang, Y., Wu, C. K. \& Yuan, J. J. (2009).The role of integrated marketing communications (IMC) on heritage destination visitations. Journal of Quality Assurance in Hospitality and Tourism, 10(1), 218-231. 